Abditani : Jurnal Pengabdian Masyarakat 1 (1) 20-27

\title{
PKM APLIKASI PENGOLAHAN SAMPAH UNTUK MENSEJAHTRAKAN MASYARAKAT RAMAH LINGKUNGAN BERBASIS INKUBATOR PAKAN TERNAK DI KOTA PALU PROVINSI SULAWESI TENGAH
}

\author{
Safriyanto S. Maruka ${ }^{1^{*}}$, Yudin Ibrahim ${ }^{1}$ \\ ${ }^{1}$ Program Studi Teknologi Pengolahan Hasil Laut, Politeknik Palu \\ Jln. Sinarkemuning 1 No. 1A Palu 94118 Sulawesi Tengah Indonesia \\ e-mail: edimaruka@yahoo.co.id
}

\begin{abstract}
ABSTRAK
Program PKM ini merupakan program pemberdayaan masyarakat yang bertujuan untuk mengembangkan kelompok masyarakat yang mandiri secara ekonomi melalui kelompok peternak ikan lele. Program PKM ini sasarannya adalah untuk membangkitkan wirausaha melalui kelompok home industri pengolahan limbah ikan. Program PKM ini akan dilaksanakan di Kelurahan Kalukubula Kecamatan Dolo Kabupaten Sigi yang memiliki potensi dekat dengan sumber air. Oleh karena itu masyarakat banyak yang berusaha melalui ternak lele. Kelompok ini merupakan kelompok mitra yang diberi nama kelompok Momi dan kelompok Mitra Sejahtera yang beranggotakan 15 orang dan dapat mempekerjakan 8 orang setiap kelompok. Metode pelaksanaan dikembangkan dalam program ini adalah metode penyuluhan dan pelatihan meliputi pelatihan teknis dan pelatihan non teknis. Pelatihan teknis merupakan pelatihan Teknologi Tepat Guna (TTG). Melalui metode ini terjadi transper pengetahuan, transper keterampilan dan transper teknologi khususnya Teknologi Tepat Guna (TGG) kepada kelompok mitra Dengan program PKM ini kelompok mitra berdaya sehingga mampu mengakses potensi yang dimilikinya Sedangkan pendekatan yang dikembangkan adalah pendekatan learning by doing artinya belajar sambil bekerja/berusaha. Oleh karena itu kelompok mitra dapat mengembangan usahanya secara berkelanjutan menuju kemandirian kelompok. Adapun alur pelaksanaan program PKM ini dimulai dari, 1) Tahap persiapan, yang terdiri dari tahap : (a) penyiapan bahan administrasi sesuai dengan kebutuhan pelaksanaan sosialisasi, (b) melakukan koordinasi dengan mitra untuk mengetahui kesiapan kelompok (c) menyiapkan jadwal sosialisasi menyesuaikan dengan perencanaan kegiatan yang telah terprogram, (d) pembagian tugas tim dalam hal pemberian materi kepada mitra sesuai kompetensi, dan (e) menyiapkan materi pelatihan 2) tahap pelaksanaan, yang terdiri dari : (a) sosialisasi pelatihan pengolahan limbah ikan menjadi pakan ternak, (b) diskusi terbatas mengenai pemahaman wawasan dan keterampilan, dan (c) praktek pelatihan langsung bagi mitra, (d) memberikan penilaian terhadap produk yang dihasilkan oleh mitra.
\end{abstract}

Kata kunci: limbah pasar, produk pakan, kelompok mitra

\section{Pendahuluan}

Kota Palu adalah ibukota propinsi Sulawesi Tengah. Seiring dengan pesatnya pertumbuhan penduduk kota Palu, maka banyak masalah yang harus diselesaikan oleh pemerintah. Salah satu diantaranya yaitu masalah pengelolaan sampah.

Menurut Hermawan dan Roesman (2012) menyatakan sudah bukan rahasia lagi sampah di Indonesia sudah menjadi masalah yang serius. Sampah dapat menjadikan lingkungan tidak sehat, tidak bersih dan tidak nyaman bahkan sampah dapat menjadi bencana bagi lingkungan hidup jika tidak ditanggulangi secara serius. Lebih lanjut dikatakan bahwa sampah banyak ditemui pada lokasi-lokasi umum, terutama pasar.

Pengelolaan persampahan di Kota Palu masih menggunakan system pengelolaan yang konvensional yaitu metode pengumpulan, pengangkutan keTPS dan pemusnahan sampah di Tempat Pembuangan Akhir (TPA), pengelolaansampah ini sangat tergantung pada armada pengangkut sampah. 
Sampah-sampah tersebut, yang terdiri dari sampah organik dan anorganik semuanya terangkut dan dimusnahkan di TPA. Disamping itu pembiayaan dalam pengelolaan sampah harus secara efektif dikelola oleh Pemerintah Daerah. Karena pada umumnya, pengelolaan sampah memerlukan anggaran/biaya yang besar, terutama untuk biaya teknik operasional dari pengumpulan, pengangkutan dan pengolahan sampai di tempat pembuangan akhir.

Pengelolaan sampah sementara ini dipandang hanya sebagai tanggung jawab pemerintah semata. Masyarakat lebih berperan hanya sebagai pihak yang dilayani, karena mereka merasa sudah cukup hanya dengan membayar uang retribusi sampah sehingga penanganan selanjutnya adalah menjadi tanggungjawab pemerintah. Padahal saat ini sudah ada sistem yang lebih baik danefisien dan dianggap modern yaitu konsep zero waste, dengan menerapkan pengelolaan sampah secara terpadu, mengurangi volume sampah dari sumbernya dengan cara daur ulang dan pengkomposan. (Damanhuri, 2013)

Saat ini Kota Palu mengalami masalah sampah yang dihasilkan dari pedagang sayur dan ikan yang berjualan terutama Pasar serta rumah makan dan unit pengolahan makanan. kecenderungan masyarakat ketika membeli ikan, langsung dibersihkan ditempat membeli ikan, terutama ikan batu, ikan rappo-rappo ikan mujair, ikan bandeng dan lain-lain. Limbah pembersihan itu meliputi insang, sisik dan perut ikan. Dalam tempo 6 jam, limbah tersebut sudah menimbulkan bau busuk yang menyengat dan menggangu lingkungan. Apalagi cara pembuanganya bersamaan dengan limbah sayur-sayuran dan lauk pauk. Karena mayoritas penjual ikan di Kota Palu dan sekitarnya, juga menjual sayur, buah, tahu, tempe dan rempah-rempah kebutuhan rumah tangga.

Dampak dari limbah yang dihasilkan menyumbang sampah yang eksrim di Kota Palu, karena disamping volume sampah secara kuantitatif, juga secara kualitatif menimbulkan bau busuk yang menyatu dengan kantongan plastic sehingga dapat menjadi polusi udara yang menggangu pernafasan. Air lindih limbah ikan juga berpotensi membuat korosi besi armada pengangkut sampah sehingga usia armada semakin pendek. Oleh karena itu setelah merumuskan beban terhitung (quantitative cost) dan beban tak terhitung (qualitative cost), maka perlu dilakukan exchange cost yaitu penyesuaian dalam pengurangan beban dalam memindahkan sebagian beban kepada pengolahan sampah sedini mungkin. Pengolahan limbah ikan menjadi tepung ikan bahan pakan ternak yang memiliki protein dan kalsium tinggi serta bernilai ekonomis, merupakan exchange cost, bahkan memberikan nilai tambah (benefit cost) terhadap hal- hal yang biasanya menjadi beban masyarakat dan beban pemerintah.

Berdasarkan pengamatan, nilai tambah tertinggi bisa didapatkan dengan mengolah limbah ikan menjadi tepung ikan (fish meal). Harga tepung ikan dipasaran sekitar Rp 5000 - Rp 9000 per kg, tergantung kandungan proteinnya. Tepung ikan tersebut sebagai bahan campuran bergizi dalam pakan ternak. Persentase tepung ikan dalam pakan ternak untuk ayam maupun itik petelor 5-10\%, itik potong $12 \%$, puyuh $10 \%$ (Dirjenak. 2010)

Program ini berbentuk pelatihan dan penyuluhan untuk membentuk industry kecil sebagai incubator pengolahan limbah ikan. Manfaat pengolahan limbah ikan yaitu untuk meningkatkan kualitas limbah ikan menjadi produk yang bernilai tinggi sehingga limbah tersebut dimanfaatkan dengan baik tanpa harus membuangnya dengan percuma. Pemanfaatan limbah ikan dimasyarakat masih sangat minim sehingga dapat menjadi suatu lapangan kerja baru bagi masyarakat. Dengan kondisi sebagaimana dijelaskan sebelumnya, peluang usaha tepung ini sangat prospektif.

Sasaran dari program PKM ini adalah kelompok ternak lele. Dengan sentuhan program PKM ini diharapkan dapat meningkatkan pendapatan bagi kelompok mitra ternak lele melalui peningkatan nilai produk. Ada dua kelompok mitra yang dijadikan sebagai kelompok mitra dalam program PKM ini yaitu kelompok MOMI 
Abditani : Jurnal Pengabdian Masyarakat

yang beranggotakan 8 orang dan kelompok PETOBO yang beranggotakan 7 orang, sehingga jumlah anggota kelompok mita sebanyak 15 orang dan dapat memperkerjakan 8 orang anggotanya dalam satu kelompok yang merupakan penduduk sekitarnya, sebagai binaan melalui program PKM. Sebenarnya kelomok mitra berkeinginan untuk memberi nilai tambah terhadap limbah ikan yang sering dibuang namun masih mengalami kendala, diantaranya belum memiliki pengetahuan yang cukup untuk membuat produk olahan limbah ikan.

Usaha pemanfaatan limbah hasil pengolahan perikanan menjadi produk bernilai ekonomis ini akan dilakukan di kelompok mitra ternak lele, sehingga dapat menghemat pengeluaran investasi awal karena tidak perlu menyewa tempat. Jadi secara prinsip, lokasi cukup mendukung untuk kegiatan usaha pemanfaatan limbah pengolahan hasil perikanan menjadi produk tepung ikan dengan nilai ekonomis lebih tinggi.

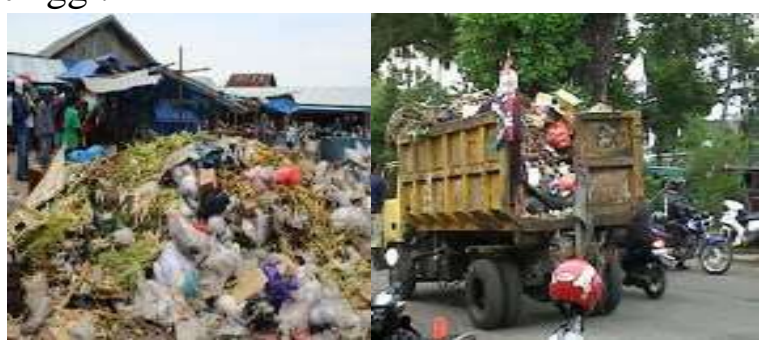

Gambar 1. Kondisi Pasar dan Armada Pengangkut Sampah di Kota Palu

Pengadaan bahan baku limbah pengolahan hasil perikanan dalam kegiatan ini diperoleh dari pedagang ikan di Pasar masomba, Pasar Inpres dan pasar Tua, yaitu dibeli dengan harga Rp. 500,- per Kg sampai ke lokasi pengolahan. Potensi limbah yang dihasilkan dari pedagang pasar ini mencapai 1 ton per hari. Untuk meningkatkan kapasitas produksi, dapat dilakukan dengan mengumpulkannya dari warung makan dan rumah tangga di wilayah Sekitar. Jadi dengan adanya kerja sama dengan pedagang ikan di ke 3 Pasar ini dan pasar-pasar lainnya, ketersediaan bahan baku tidak menjadi persoalan lagi.

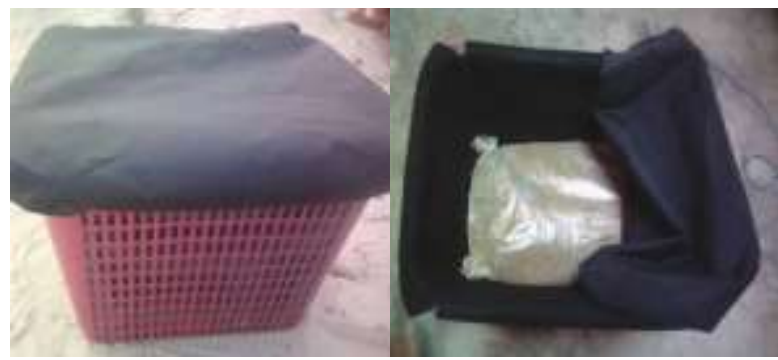

Gambar 2. Teknologi Tempat Penampung Limbah Ikan Di Pasar dan Rumah Makan

Pasar yang sudah pasti saat ini adalah para peternak ayam pedaging dan petelor di daerah kota Palu dan sekitarnya yang setiap harinya membutuhkan puluhan ton tepung ikan sebagai bahan baku dalam pembuatan ransum pakan ternak mereka. Selain itu, petrnak ikan juga sangat membutuhkan tepung ikan untuk bahan baku pembuatan pellet ikan yang sedang dikembangkan. Dilihat dari potensi pasar yang sudah siap menampung tepung ikan yang akan dihasilkan, masalah pemasaran produk bukan menjadi kendala yang bearti lagi, dengan catatan perlu dijaga Kualitas, Kuantitas dan Kontinyuitas produksi tepung ikan yang akan dihasilkan. Dengan adanya usaha pengolahan limbah-limbah hasil perikanan menjadi produk tepung ikan, maka dampak polusi akibat bau dan kotoran yang ditimbulkan oleh penumpukan limbah ikan ini dapat dikurangi. Secara tidak langsung usaha ini juga membantu Pemerintah dalam mengatasi permasalahan penanggulangan sampah kota di Palu. Ditinjau dari peluang kesempatan kerja bagi penduduk sekitarnya, kegiatan ini akan menampung sejumah tenaga kerja yang dapat direkrut dari penduduk sekitar lokasi mitra. Jadi dampak negatif dari kegiatan ini dapat dikurangi, bahkan lebih banyak nilai positifnya.

\section{Metode Pelaksanaan}

Metode pelaksanaan dan pendekatan yang akan dikembangkan dalam kegiatan program PKM ini dapat mengatasi permasalahan yang dihadapi kelompok mitra. Dalam program PKM ini, metode dan 
Abditani : Jurnal Pengabdian Masyarakat 1 (1) 20-27

e-ISSN : 2622-4690

p-ISSN : 2622-4682

pendekatan yang dikembangkan yaitu sebagai berikut:

\section{Tahap Persiapan}

\section{a. Lokasi dan Waktu Kegiatan}

Lokasi kegiatan PKM ini akan dilaksanakan di Kelurahan Kalukubula Kecamatan Dolo Kabupaten Sigi Provinsi Sulawesi Tengah. Di Kelurahan ini Kelompok Mitra melakukan aktivitas ternak lele. Kelurahan ini juga strategis dengan sumber bahan baku limba ikan, dikarena lokasinya berdekatan dengan pasar terbesar di Kota Palu. . Kegiatan PKM ini direncanakan dilaksanakan pada bulan April 2018.

\section{b. Persiapan Kelompok Mitra}

Sebelum pelaksanaan kegiatan ini kelompok mitra di persiapkan, untuk ikut pelatihan sebagai tahap proses pelaksanaan kegiatan, oleh karena itu sebelum dilaksanakan kegiatan PKM maka dilakukan pertemuan dengan kelompok mitra, untuk mengetahui kesiapan kelompok mitra

\section{Pelaksanaan}

Metode pelaksanaan program PKM ini meliputi dua hal yaitu sebagai berikut:

a. Metode Penyuluhan

Metode penyuluhan merupakan salah satu metode yang akan dikembangkan dalam program PKM. Metode penyuluhan ini sangat penting pada anggota kelompok mitra untuk menambah pengetahuan sehingga terjadi perubahan kognitif. Artinya pola pikir yang dirubah terlebih dahulu untuk memudahkan proses kegiatan PKM selajutnya. Bentuk penyuluhan dapat dilakukan melalui survey antar porsonal secara tatap muka. Selain itu bisa dilakukan secara kelompok, atau melalui media. Metode ini juga sebagai ajang sosialisasi program.

b. Metode Pelatihan

Metode pelatihan yang dikembangkan dalam program PKM ini meliputi dua bentuk pelatihan yaitu:

1) Pelatihan teknis

Pelatihan teknis pengolahan bahan baku limbah ikan menjadi pakan ternak. Metode ini merupakan salah satu solusi dalam menengani sampah di Kota Palu. sedangkan untuk penanganan limbah dari produksi tepung ikan dapat di olah menjadi pupuk organik untuk tanaman. Adapan alat dan bahan serta alur proses pembuatan yaitu sebagai berikut (Badan Standardisasi Nasional. 2009):

- Alat dan bahan

Alat yang digunakan diantaranya

Mesin Penggiling Tepung, (2) Oven,

Ember dan baskom, (4) Sendok makan dan sendok kayu dll (5) Parang 6. Karung dan keranjang Sedangkan Bahan yaitu sebagai berikut: (1) Limbah Ikan, (2) Starter, (3)Air.

- Alur proses pembuatan tepung ikan.

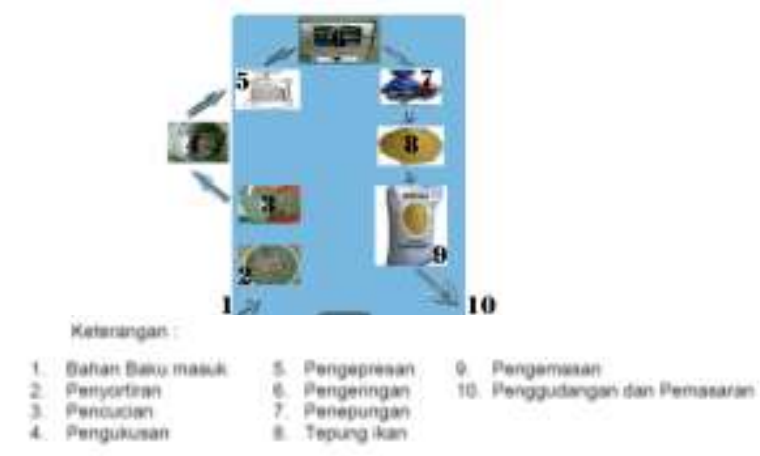

2) Pelatihan Non Teknis

Pelatihan Non Teknis ini, yang akan dikembangkan adalah berhubungan dengan permasalahan kelompok mitra. Sehubungan dengan itu maka materi kegiatan yang akan dibahas dalam pelatihan non tehnis yaitu yaitu sebagai berikut:

a. Prosespek pengolahan limbah kini dan masa yang akan datang.

b. Strategi permasaran dalam pengembangan usaha tepung ikan.

c. Manajemen kewirausahaan kelompok (aplikasi pembukuan keuangan kelompok )

d. Penguatan kelembagaan kelompok mitra.

\section{Pendekatan / Pendampingan Pelatihan)}

(Pasca

Untuk mengembangkan program PKM bagi pengolahan tepung ikan yang berkelanjutan maka dalam program PKM maka dikembangkan pendekatan yang dinamakan Learning by doing artinya belajar 
sambil bekerja/berusaha. Pendekatan ini sangat penting untuk pengembangan usaha.

Agar program PKM ini berkelanjutan dilakukan pendampingan terhadap kelompok mitara baik teknis maupun non teknis. Oleh karena itu maka ada beberapa yang dilakukan dalam proses pendampingan yaitu sebagai berikut:

a. Pembelajaran kelompok

Sebelum pembelajaran dikelompok dimulai maka yang perlu dilakukan awal adalah persiapan peralatan dan bahan atau sarana pembelajaran, oleh karena it yang perlu dilakukan adalah penyerahan bantuan stimulan sebagai dana oporasional. Setelah bahan dan alat atau sarana pembelajaran siap maka dilakukan pembelajaran, yang didampingi oleh penyelenggara atau pendamping khusus. Pembelajaran kelompok ini dilaksanakan di masingmasing kelompok mitra yaitu Kelompok mitra Momi dan kelompok mitra Petobo. Pembelajaran dikelompok ini merupakan suatu proses untuk menguji keterampilan yang diterima dari pelatih. Pembelajaran dikelompok ini akan dilaksanakan berulanulang kali sebagai proses pembejalaran. Dalam proses pembelajaran dikelompok ini pada dasarnya sudah menghasilkan produk yang akan dijual kepasaran. Pendekan inilah yang dinamakan learning by doing artinya belajar sambil bekerja. Dalam proses pembejaran dikelompok ini didampingi oleh pendamping khusus diluar penyelenggara. Kegiatan pembelajaran merupakan cikal bakal usaha yang akan dikembangkan oleh anggota kelompok masing-masing. Oleh karena itu dalam proses pembelajaran kelompok ini sudah dilaksanakan proses pembukuan keuangan kelompok karena sudah terjadi proses penjualan produk.

b. Proses pemasaran

Hasil pembelajaran dikelompok merupakan produk awal berupa tepung ikan dari kelompok mitra dari program PKM. Oleh sebab itu produk yang dihasilkan dalam pembelajaran sudah merupakan penghasikan dari usaha kelompok mitra. Dengan terkumpulnya produk tesebut maka perlu dipasarkan atau dijual. Proses penjualan atau pemasaran produk turunan limbah ikan ini didampingi oleh pendamping dalam program ini.

\section{Monitoring dan Evaluasi}

Selain pendampingan maka dilakukan monitoring dan evaluasi sebagai salah satu bentuk pembinaan. Dalam pelaksanaan program PKM ini akan dilakukan monitoring dan evaluasi program kegiatan dilapangan atau diintitusi. Lembaga yang akan melakun monitoring penyenggaraan program yaitu Direktur dan P3KM Politeknik Palu Palu, Kopertis Wilayah IX, dan DRPM.

Dalam penyelenggaraan PKM ini pihak P3KM dan Direktur Politeknik Palu melakukan kunjungan lapangan untuk melihat proses pelaksanaann program PKM. Sedangkan untuk DRPM melakukan monitoring dan evaluasi biasanya dua kali yaitu pada saat pertengan dan pada saat akhir tahun anggaran. Pada saat dilakukan monitoring dan evaluasi pertengan dilakukan ditingat provisi yang biasanya dikumpul di Universitas Muhammadiyah Palu, setiap penerima akan mempersentasekan hasil kegiatannya yang dibuktikan produk fisik. Selain itu dilakukan kunjungan lapangan. Selanjutnya monitoring dan evaluasi di akhir tahun biasaya dilaksanakan di Makassar yang dihadiri peremima dana PKM di Kawasan Indonesia Timur. Bentuk Evaluasinya Prosentase perkembangan hasil akhir kegiatan PKM.

\section{Hasil dan Pembahasan}

\section{Pelaksanaan Kegiatan}

Pelaksanaan kegiatan Pengabdian kepada Masyarakat dengan judul : PKM Aplikasi Pengolahan Sampah Untuk Mensejahterakan Masyaraka Ramah Lingkungan Berbasis Inkubator Pakan Ternak. Dalam kegiatan PKM ini, yang dimulai dari bulan Mei sampai pada bulan November 2018 telah dilaksanakan 100\% program dilaksanakan dengan pendampingan dan beberapa kali tatap muka. Kegiatan pengabdian masyarakat ini dilakukan dalam bentuk transfer iptek untuk menyelesaikan permasalahan yang dihadapi oleh mitra 
Abditani : Jurnal Pengabdian Masyarakat 1 (1) 20-27

e-ISSN : 2622-4690

p-ISSN : 2622-4682

dalam kaitannya dengan upaya pengembangan wawasan pengetahuan dan keterampilan pengolahan pakan ternak yaitu berupa : sosialisasi, pelatihan non teknis (prosespek pengolahan pakan ternak yang akan datang, strategi permasaran dalam pengembangan usaha. Manajemen kewirausahaan kelompok, penguatan kelembagaan kelompok mitra), pelatihan pengolahan limbah menjadi bahan baku pakan ternak.

Adapun alur pelaksanaan program PKM ini dimulai dari, 1) Tahap persiapan, yang terdiri dari tahap : (a) penyiapan bahan administrasi sesuai dengan kebutuhan pelaksanaan sosialisasi, (b) melakukan koordinasi dengan mitra untuk mengetahui kesiapan kelompok (c) menyiapkan jadwal sosialisasi menyesuaikan dengan perencanaan kegiatan yang telah terprogram, (d) pembagian tugas tim dalam hal pemberian materi kepada mitra sesuai kompetensi, dan (e) menyiapkan materi pelatihan 2) tahap pelaksanaan, yang terdiri dari : (a) sosialisasi pelatihan pengolahan limbah ikan menjadi pakan ternak, diskusi terbatas mengenai pemahaman wawasan dan keterampilan, dan (c) praktek pelatihan langsung bagi mitra, (d) memberikan penilaian terhadap produk yang dihasilkan oleh mitra.

Menyelesaikan semua permasalahan yang dihadapi mitra, maka dilakukan kegiatan pelatihan dengan berbagai tahapan karena mitra berbeda-beda sehingga waktu pelaksanaan tidak sama. Sebelum pelaksanaan kegiatan tim mengadakan acara pembukaaan pada Hari Kamis Tanggal 12 Juli 2018 Pukul 15.00-17.00 WIT dengan tujuan menjelaskan kegiatan dan pelaksanaannya.

Permasalahan pertama adalah mengatasi kendala limbah ikan yang beredar dipasaran dan warung makan dengan cara mengatasinya diperlukan pengolahan limbah ikan menjadi bahan baku pakan ternak. Kemudian permasalahan kedua biaya produksi lele konsumsi akibat biaya pakan yang sangat mahal. Saat ini harga pakan berupa pelet untuk lele produksi pabrikan adalah Rp. 1100/kg dan menyita 50-70\% biaya produksi. Untuk mengatasinya maka diperlukan upaya menyediakan pakan berupa pelet secara mandiri oleh kelompok dari bahan yang muda didapat.

Langkah yang dilakukan adalah pelatihan teori dan praktek pembuatan pakan lele atau pelet dengan memanfaatkan bahan sekitar atau lokal sehingga harga pakan dapat ditekan. Selama ini bahan baku pembuatan pakan sebenarnya tersedia cukup banyak, misalnya bekatul, bekicot, ampas tahu, singkong, pati onggok, daun singkong, daun pepaya, dan tepung ikan yang terbuat dari limbah ikan. Pelet yang dibuat sendiri mampu dijual dengan harga Rp. 9000/kg yang berarti lebih murah Rp. $2.000 / \mathrm{kg}$. Pelatihan diberikan selama 1 kali tatap muka, dengan tujuan meningkatkan pengetahuan dan ketrampilan kelompok dalam memproduksi pakan berupa pelet untuk meningkatkan produksi lele konsumsi. Peserta adalah kelompok pemuda yang belum bekerja dan pembudidaya ikan sebanyak 15 orang sebagai kader.

Pelaksanaan pelatihan dilakukan baik secara teori maupun praktek dengan narasumber dari tim PKM serta seorang praktisi pengolah limbah ikan pelet organik dengan Tujuan pelatihan teori adalah agar peserta memahami berbagai juenis bahan local yang dapat digunakan sebagai bahan baku. Materi yang diberikan adalah pemanfaatan bahan lokal sebagai bahan baku pembuatan pakan (pelet) dan praktek tentang prosedur pembuatan pakan (pelet) dengan benar dan menghasilkan pelet yang baik dan ringan sesuai kriteria. Pelatihan dilaksanakan sebanyak 5 kali tatap muka, yaitu 2 kali tatap muka teori dan 3 kali tatap muka praktek. Metode pelatihan yang digunakan adalah ceramah, tanya jawab, diskusi dan latihan.

Untuk mendukung keberhasilan pelatihan dan produksi diberikan bantuan alat pembuat pellet dan alat penepung. Pelatihan diharapkan dapat meningkatkan pemahaman ketrampilan peserta dalam membuat pellet dan tepung ikan guna pakan ternak unggas . Selama pelatihan diharapkan $100 \%$ peserta 
Abditani : Jurnal Pengabdian Masyarakat

hadir dan mengikuti pelatihan sampai selesai demi kemajuan usaha bersama.

Pelatihan dilanjutkan dengan pelatihan praktek, pelatihan dilaksanakan di lokasi rumah kompos milik praktisi praktisi pelet organik, Bapak Dr. Syamsuri Akil beliau adalah praktisi pengolahan sampah sebagai pakan ternak pelet yang sudah berpengalaman dalam pembuatan pelet mandiri dan memiliki budidaya lele. Pelatihan perlu mengundang praktisi pelet yang sudah mempraktekkan penggunaan pelet mandiri dalam budidaya lele. Hal ini perlu dilakukan karena salah satu kendala pelet mandiri yang dibuat dengan alat pelet local seringkali tenggelam. Kondisi menjadi kendala karena dapat mengganggu kesehatan lele dan ikan yaitu dapat terserang jamur karena mengotori kolam, serta jumlah konsumsi oleh ikan menjadi tidak terdeteksi. Padahal anjuran pemerintah dan pembudidaya lele Kabupaten Sigi sebaiknya pembudidaya lele membuat pakan sendiri agar biaya produksi dapat ditekan. Lele termasuk jenis ikan yang tingkat konsumsinya sangat rakus sehingga menyita biaya produksi. Perbedaan pelet pabrik adalah ringan dan mengapung karena dibuat dengan alat ekstruder, harga alat untuk pembuatan pelet model pabrik sekitar Rp. 60.000.000 sehingga tidak mungkin bagi petani lele untuk membuat sendiri.

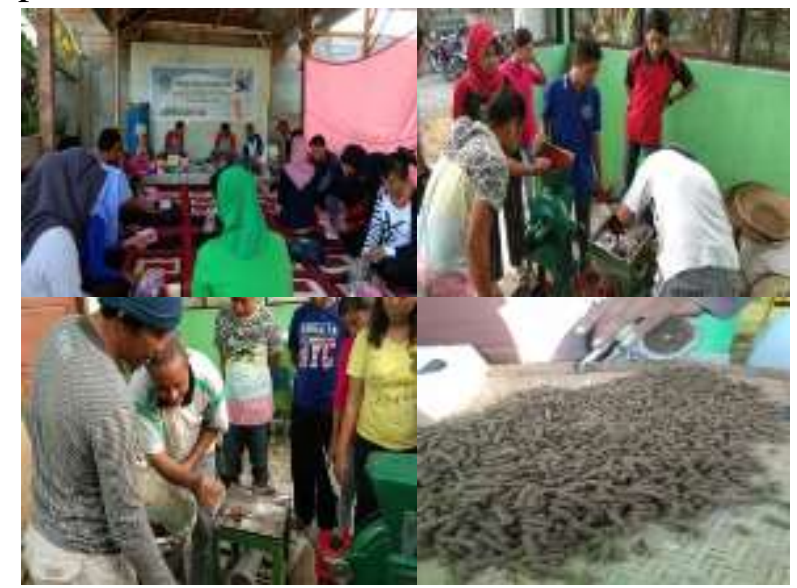

Gambar 2. Pelatihan Teori dan Pelatihan Praktek Pencetakan Pencetakan Pelet

Narasumber yang kami undang telah berpengalaman dalam membuat pelet dengan alat local, pelatihan praktek dilaksanakan
e-ISSN : 2622-4690

p-ISSN : 2622-4682

pada Hari Jumat 13 Juli 2018. Bahan baku utama yang digunakan adalah bekatul, daun pepaya, dan limbah ikan. Proses pembuatan cukup mudah dan pengeringannya tidak memerlukan alat khusus. Hasil pelet organik yang dihasilkan memiliki kelebihan dibanding pelet pabrik, yaitu:

1. Bahan baku tersedia dan murah dengan bahan utama bekatul yang tersedia berlimpah di sekitar lokasi

2. Pembuatan mudah dan tanpa bahan kimia sehingga tergolong pelet organik dan hasilnya menjadi lele organic

3. Pelet tidak berbau (sementara pelet pabrikan berbau cukup menyengat)

4. Tidak memerlukan alat pengering tetapi cukup dikeringkan di bawah sinar matahari tetapi dengan jalan dibuatkan gubugan yang ditutup plastik hitam

5. Hasil penelitian pelet limbah ikan memiliki kandungan protein dan kalsium yang tinggi

Kegiatan berjalan lancar dengan bantuan alat pembuat pelet berupa 1 unit alat penepung dan 1 unit pencetak pelet. Alat tersebut menghasilkan 2 ukuran pelet, yaitu pelet halus untuk pembibitan lele dan pelet butiran untuk pembesaran lele. Selama kegiatan $90 \%$ peserta hadir dan mengikuti pelatihan dengan baik sehingga sasaran telah memiliki pengetahuan dan ketrampilan pembuatan pelet.

\section{Kendala Yang Dihadapi}

Dalam pelaksanaan kegiatan pengabdian pada masyarakat kami tim pelaksana kegiatan menemui beberapa kendala yaitu : kelompok belum bisa memproduksi untuk memenuhi pasaran, dikarenakan hasil produksi pakan yang berbahan baku limbah ikan harus dilakukan berbagai kajian ilmiah yang mendalam, serta meyakinkan kepada konsumen tidak begitu cepat untuk menerima produk yang dihasilkan kelompok.

\section{Kesimpulan dan Saran Kesimpulan}

1. Pelaksanaan program kegiatan pengabdian kepada masyarakat mencapai keberhasilan 
Abditani : Jurnal Pengabdian Masyarakat 1 (1) 20-27

e-ISSN : 2622-4690

p-ISSN : 2622-4682

tidak terlepas dari dukungan dan kerjasama dari pihak mitra, keberhasilan ini terlihat dari pelatihan pengolahan limbah ikan menjadi bahan baku pakan ternak berjalan sesuai prosedur.

2. Pelaksanaan program mampu menghasilakan luaran-luaran yang diharapkan oleh program pengabdian kepada masyarakat ini, kecuali memproduksi untuk pasaran, karena harus dilakukan berbagai macan kajian

\section{Saran}

Dalam rangka meningkatkan transfer iptek kepada masyarakat kelompok usaha kecil hendaknya kegiatan pengabdian pada masyarakat digalakan sehingga kemampuan masyarakat dapat ditingkatkan sekaligus dapat meningkatkan pendapatan masyarakat serta dapat membuka lapangan kerja bagi masyarakat lain.

\section{Ucapan Terimakasih}

Terima kasih kepada DRPM RISTEKDIKTI yang telah membiayai kegiatan Program Kemitraan Masyaraka Tahun 2018

\section{Daftar Pustaka}

Badan Pusat Statistik Kota Palu, 2015, Kota Palu dalam Angk, Palu

Badan Standardisasi Nasional. 2009. Standar Nasional Indonesia (SNI) Tepung Ikan. Badan Standardisasi Nasional (BSN). Jakarta.

Damanhuri, Enri, 2013, "Permasalahan dan Alternatif Teknologi Pengelolaan Sampah Kota di Indonesia" , Prosiding Seminar Teknologi untuk Negeri, Vol. I. Hal. 394400

Dirjenak. 2010. Analisa Pembangunan Pabrik Pakan Ikan Skala Kecil dan Proses Pengolahan Pakan. Direktorat Ternak Non Ruminansia. Direktorat Jendral Peternakan. Jakarta.

Hermawan dan Roesman. 2012. Perilaku Pedagang Sayur Dalam Mengelola Kebersihan Lingkungan Hidup. Jurnal Bumi Lestari Vol. 8 No. 2. Tasikmalaya: Universitas Siliwangi.

Kastasasmita , Ginanjar, 2013, Pembangunan untuk Rakyat, Jakarta, ustaka, Cidesindo 